\title{
CLLU1 wt Allele
}

National Cancer Institute

\section{Source}

National Cancer Institute. CLLU1 wt Allele. NCI Thesaurus. Code C104156.

Human CLLU1 wild-type allele is located in the vicinity of 12 q22 and is approximately 70 $\mathrm{kb}$ in length. This allele, which encodes chronic lymphocytic leukemia up-regulated protein 1 , may play a role in chronic lymphocytic leukemia. 